\title{
INTERNAL CONTROL SYSTEMS AND ITS RELATIONSHIPS WITH THE FINANCIAL PERFORMANCE IN TELECOMMUNICATION COMPANIES "A CASE STUDY OF ASIACELL"
}

\author{
Amanj Mohamed Ahmed \\ Darbandikhan Technical Institute, Sulaimani Polytechnic University / Sulaimani, \\ Kurdistan Region, Iraq \\ amanj.mohamed@spu.edu.iq \\ Akram Ahmed Muhammed \\ Dukan Technical Institute, Sulaimani Polytechnic University / Sulaimani, Kurdistan \\ Region, Iraq \\ akram.muhammd@spu.edu.iq
}

\begin{abstract}
The overall objective of this study was to establish the effects of internal controls on the financial performance of Asiacell as a telecommunication company in Kurdistan Region of Iraq. This was achieved by looking at the effect of control environment, risk assessment, information and communication, control activities and monitoring on the return on asset of the selected company. The study used both primary and secondary techniques to collect the data. In the model, the dependent variable is financial performance while the independent variables are the components of internal controls. After analyzing the audited financial statements and filling the questioners by the employees of the selected company, the findings of the study showed that there is a significant relationship between internal controls and financial performance. The dependent and the independent variables in the study indicated a relationship with control environment, risk assessment. Information and communication and control activities illustrated a positive relationship with the financial performance while monitoring showed a negative relationship with financial performance. The study also found that, Asiacell had invested on effective internal control systems, thus, it had a better financial performance as compared to the related firms that had a weak internal control system. The study further recommends that the governing body, possibly supported by the audit committee, should ensure that the internal control system is periodically monitored and evaluated by the respective managers.
\end{abstract}

\section{Keywords}

Internal Controls; Component of Control; Financial Performance and Telecommunication Company in Kurdistan Region

\section{JEL Classification}

M41

\section{Introduction}

Internal controls are strategies set by the companies to ensure the integrity of financial and accounting information, meet operational and productivity targets, and transmit administration arrangements all through the association (Shokoohi et al, 2015; Channar et al, 2015; Ngari, 2017; Eniola \& Akinselure, 2016; Asiligwa, 2017; Hamed, 2009 and Bett \& Memba, 2017). Internal controls work best when they are connected to the different divisions and manage the communications between the different business offices (Treba, 2003 and Bett \& Memba, 2017). While little frameworks of internal control are indistinguishable, yet many center methods of insight in regards to monetary 
trustworthiness and bookkeeping rehearses have turned out to be standard administration hones (Asiligwa, 2017). It is important that internal controls just give sensible however not outright affirmation to an entity's management and board of directors that the firm's goals will be accomplished (Hayes et al, 2005). "The likelihood of achievement is affected by limitation inherent in all systems of internal control" (Hayes et al, 2005).

Cunningham (2004) states that the framework of internal control starts as inner procedures with the positive in order to help the company to meet the destinations. Administration principally gives oversight actions. It sets the substance of destinations and has generally speaking obligation over the internal control systems (Cunningham, 2004). Internal controls are an indispensable piece of any organization's financial and business approaches and systems (Nyakundi, 2014 and Vadiei \& Kuchaky, 2008). Inside controls comprise of the considerable number of measures taken by the association with the end goal of; securing its assets against waste, extortion and wastefulness; guaranteeing precision and unwavering quality of bookkeeping and working information; guaranteeing consistency with the strategies of the association; assessing the level of execution in every hierarchical unit of the association (Enwelum, 2013 and Ngwenya, 2013).

In addition, a sound of internal control systems can help the organizations to prevent frauds, errors and minimize wastage (Uket \& Joseph 2012 and Eniola \& Akinselure, 2016). Custody of assets is strengthened because it provides assurance to the management on the dependability of accounting data that eliminates unnecessary suspicion and helps in maintenance of adequate and reliable accounting records (Fernando et al, 2012; Kaplan, 2008; COSO, 2011 and Asiligwa, 2017). Regardless of the way that internal control framework is costly to introduce and keep up, it gradually developed throughout the years with the best improvement happening toward the start of 1940's (Cunningham, 2004). Not just have the complexities of the business procedures added to this improvement, additionally the expanded size of specialty units, which have energized the selection of techniques is helpful to expand the productivity of business because it goes against errors and frauds (Cunningham, 2004; COSO 1985; COSO 1992 and Asiligwa, 2017).

Mawanda (2008), states that "there is a general recognition that establishment and requirement of appropriate inside control framework swill dependably prompt enhanced money related execution". It is likewise a general conviction that appropriately organized frameworks of internal control enhance the revealing procedure and furthermore offer ascent to solid reports which improves the response capacity of administration of a substance. Get ready dependable monetary data is a key obligation of the administration of each open organization (Cahill, 2006; Inusah \& Abdulai, 2015; Kaplan, 2008 and Rahmany, 2013).

Further, positive financial performance in a telecommunication company can be accomplished by annihilating waste in benefits of administration procedures and framework. The "basic achievement factor" for a telecommunication company is how much it satisfies its set goals and mission regarding being productive, successful and sparing (Hayes et al, 2005 and Shokoohi et al, 2015). The data acquired from a sound inward control framework as reflected from monetary articulations will give a provide details regarding a firm's money related execution (Hayes et al, 2005). In this essence, internal control systems are very instrumental in achieving the firm's set mission and objectives. The main approach to value for money is the firm's control over the use of resources in order to achieve its set objectives (Hayes et al, 2005). Thus, head of 
departments should establish sound arrangements for planning, appraising, authorizing and controlling operations in order to achieve positive financial performance.

Dixon et al (1990) also discovered that fitting execution measures are those which empower associations to coordinate their activities towards accomplishing their key objectives. Collins (2014) alludes to execution as the capacity to work effectively, productively, survive, develop and respond to the natural open doors and dangers. As of late the part of internal control framework has accomplished awesome significance since it is intended to protect the company's resources against abuse, guarantee consistency with the company's laid arrangements, guarantee the company's workforce are productively used and the organization keeps running in a deliberate and effective way. Therefore, the purpose of this study is to investigate and establish the relationship between internal control systems and the financial performance of Telecommunication Company in Kurdistan Region of Iraq.

\section{Problem Statement}

Despite the fact that internal control systems have been considered by many telecommunication companies, but still they have an issue with poor financial performance, manipulating financial statements and fraudulent in using the company's assets. Thus, this study will investigate to find that is there any relationships between internal control systems and financial performance in telecommunication companies.

\section{Objectives of the study}

The main objectives of this paper are to: (i) show how useful is internal controls to organizational performance in telecommunication companies, (ii) explorer the relationship between the components of the internal control and the financial performance of Asiacell as a telecommunication company in Kurdistan Region of Iraq.

\section{Literature review}

\section{Theoretical Review}

Various theories have been developed on internal control, internal audit and financial performance. This paper describes some of them as follows:

\section{Agency Theory}

The agency theory proposes that a firm's main objective is to amplify the investors' riches. The theory expresses that the association comprises of principals who are the proprietors of the financial assets and the agents who are the supervisors of the company's assets (Jensen \& Meckling, 1976; Jussi \& Petri, 2004; Tuan 2015; Al-Matari et al, 2014 and Ngari, 2017). The specialists don't generally partake in the principals destinations and may on occasion act to promote their own particular advantages at the investor's cost. Thus, internal control is one of many mechanisms that used in business to address the agency problem. Also include financial reporting, budgeting, audit committees, and external audits. This argument assumed that providing this additional information to the shareholders about the behavior of the management reduce information asymmetry and lowers investors risk and, therefore, the cost of equity capital (Jensen \& Meckling, 1976). 


\section{Contingency Theory}

Contingency theory is utilized to describe the connections between the context and structure of internal control effectiveness and organizational performance, especially reliability of financial reporting. Empirical study proposes that internal auditors who are specialized and higher in internal audit capacity will accomplish viable internal controls that help the firm to earn more profit (Cadez \& Guilding, 2008 and Woods, 2009).

\section{Determinants of Financial Performance}

Financial performance alludes to how much budgetary targets being or has been proficient. It is the way toward measuring the consequences of a firm's arrangements and operations in financial terms (Whittington \& Pany, 2001). It is a subjective measure of how well a firm can utilize resources from its essential method of business and generate revenues (Ejoh \& Ejom, 2014). Financial performance is utilized as a general measure of a firm's general money related wellbeing over a given time frame, and can be utilized to look at comparative firms over a similar industry or to compare industries or sectors in aggregation. Details, for example, revenue from operations, operating income or cash flow from operations can be utilized, as well as total unit of sales (Ejoh \& Ejom, 2014).

Further, internal control includes various techniques and measures that are practiced by the management to guarantee smooth and monetary working of a business substance (Kumar \& Sharma, 2005). Hence, it is intended to give sensible affirmation that the entity's general targets are being accomplished (Ejoh \& Ejom, 2014). This is also supported by Kumar \& Sharma (2005), they argued that clear targets are an essential for an effective internal control process. The general targets being achieved include; executing orderly, moral, economical, efficient and effective operations, satisfying responsibility commitments, consenting to appropriate laws and regulations and defending assets against loss, abuse and harm. Internal control consists of five interrelated components namely; control environment, risk assessment, control activities, information and communication and monitoring.

\section{Control Environment}

A study conducted by (Ntongo, 2012 and Whittington \& Pany, 2001) the control environment is influenced by the history and the culture of organizations and has an insidious influence on the way organization activities are structured.

\section{Risk Assessment}

Risk Assessment refers to the identification and investigation of applicable dangers related with accomplishing the destinations of the association (COSO, 2011 and Lannoye, 1999).

\section{Control Activities}

They include a range of detective and preventive activities such as; Authorization and approval procedures, segregation of duties (authorizing, processing, recording, reviewing), controls over access to resources and records, verifications, reconciliations, supervision, reviews of operating performance and reviews of operations, processes and activities (Aikins, 2011 and COSO, 2011). 


\section{Information and communication}

According to Asiligwa (2017) information systems produce reports that contain operational, financial and non-financial and compliance-related information and that make it possible to run and control the operation.

\section{Monitoring}

Ongoing monitoring activities cover each of the internal control components and involve action against irregular, unethical, uneconomical, inefficient and ineffective internal control systems. Monitoring can be achieved by regularly supervising and managing activities like monitoring of customer complaints and feedback and audits that conducted periodically by internal auditors (Bowrin, 2004 and Simmons, 1995).

\section{Review of Empirical Studies}

Mawanda (2008) conducted a research on effects of internal control systems on financial performance in institution of higher learning Uganda. In his examination, he explored and looked to set up the connection between internal control systems and financial performance in an Institution of higher learning in Uganda. Internal controls were looked at from the perspective of control environment, internal audit and control activities, whereas financial performance focused on liquidity, accountability and reporting as the measures of financial performance. The researcher set out to build up the reasons for steady poor financial performance from the viewpoint of internal controls. The examination set up a critical connection between internal control system and financial performance. It suggests capability profiling in the internal audit division which ought to be founded on what the University anticipates that the internal audit will do and what fitting number staff would be required to carry out this job. The examination accordingly recognized part of internal audit division to set up internal controls which affect the money related execution of organizations.

Olumbe (2012) conducted a study to establish the relationship between internal controls and corporate governance in commercial banks in Kenya. The researcher conducted a survey of all the 45 commercial banks in Kenya. It was presumed that the majority of the banks had joined the different parameters which are utilized for gaging internal controls and corporate governance. This was shown by the methods which were acquired the Kenya's procedures. The results demonstrated that banks had established great corporate governance with a strong system of internal controls and that there is a connection between internal control and corporate governance.

A study connected by Wainaina (2011) examined the internal control function. The researcher established that, other than the prevention and detection of fraud, internal controls should reflect the quality of the general bookkeeping condition in an association and in addition to the precision of its financial and operational records as well.

\section{Hypothesis of the Study}

The study attempts to test the following hypothesis:

1- H1: Control Environment and financial performance is positively correlated.

H0: Control Environment and financial performance is negatively correlated.

2- H1: Risk Assessment and financial performance is positively correlated.

H0: Risk Assessment and financial performance is negatively correlated.

3- H1: Control Actives and financial performance is positively correlated.

$\mathrm{H} 0$ : Control Actives and financial performance is negatively correlated.

4- H1: Information and Communication and financial performance are positively correlated. 
H0: Information and Communication and financial performance are negatively correlated.

5- H1: Monitoring and financial performance is positively correlated.

H0: Monitoring and financial performance is negatively correlated.

\section{Research Methodology}

\section{Research Design}

The research design that was adopted for this study is hypothesis testing research design. The study tested the above hypothesis in detail. This sort of research design that was chosen subsequent to consider the kind of universe and its nature, the targets of the study, the testing outline and the design standard of accuracy. This is because the production of a sound internal control framework in a telecommunication company enormously impacts the area of study.

\section{Nature of the Data}

Ary et al (2006) notes that there are two major sources of data that can be used by the researchers, that is primary and secondary data. This study also relied on both techniques. Primary data was collected by using observation and analyzing the results of the questionnaires while the secondary data was gathered from the audited financial statements of "Asiacell" based on availability and accessibility of data.

\section{Data Analysis}

The statistical instrument that was utilized as a part of the study is Multiple Regression (r2). It was utilized to discover the relationships between internal controls and financial performance. Data analysis was finished by utilizing "Statistical Package for Social Sciences" (SPSS Version 22.0) program, using one way ANOVA, Regression, and Correlation. The model communicating and the speculated connection between the independent variables are (Control environment, Risk Assessment, Control Activities, Information and Communication and Monitoring) and the dependent variable is (Financial Performance of Asicell as a Telecommunication Company in Kurdistan Region). Particularly the regression model utilized as a part of this study was;

\section{$\mathrm{FP}=\mathrm{B} 0+\mathrm{B} 1 \mathrm{C} 1+\mathrm{B2C} 2+\mathrm{B3C} 3+\mathrm{B} 4 \mathrm{C} 4+\mathrm{B5C} 5+\mathrm{e}$}

Where,

FP - Financial Performance of Asiacell.

B0 - Constant

$\mathrm{C} 1$ - Control Environment

C2 - Risk Assessment

C3 - Control Activities

$\mathrm{C} 4$ - Information and Communication

C5 -Monitoring

$\mathrm{B} 1$ - B5= Measure of sensitivity of variable $\mathrm{C}$ to changes in FP $\mathrm{e}=$ Error term

\section{Data Analysis and Interpretation}

This section presents analysis and findings of the study as set out in the research objective and research methodology. 


\section{Response Rate}

The study targeted 30 respondents from the Asiacell employees. Out of the 40 questionnaires administered by the researchers, 30 filled questionnaires were collected that translated to $75 \%$ as a response rate. According to Babbie (2002), any response of $50 \%$ and above is adequate for analysis and therefore, the response rate of $75 \%$ is satisfactory.

\section{Correlation Analysis}

Table 1 Correlation matrix

\begin{tabular}{|c|c|c|c|c|c|c|c|}
\hline & & $\begin{array}{c}\text { Control } \\
\text { Environment }\end{array}$ & \begin{tabular}{|c|} 
Risk \\
Assess- \\
ment
\end{tabular} & \begin{tabular}{|c|} 
Info and \\
Communications \\
System
\end{tabular} & $\begin{array}{c}\text { Control } \\
\text { Activities }\end{array}$ & Monitoring & $\begin{array}{c}\text { Financial } \\
\text { Performance }\end{array}$ \\
\hline \multirow[t]{3}{*}{$\begin{array}{l}\text { Control } \\
\text { Environment }\end{array}$} & $\begin{array}{l}\text { Pearson } \\
\text { Correlation }\end{array}$ & 1 & -.303 & $.565^{* *}$ & $.625^{* *}$ & $.499^{* *}$ & .887 \\
\hline & Sig. (2-tailed) & & .104 & .001 & .000 & .005 & .124 \\
\hline & $\mathrm{N}$ & 30 & 30 & 30 & 30 & 30 & 30 \\
\hline \multirow[t]{3}{*}{$\begin{array}{l}\text { Risk } \\
\text { Assessment }\end{array}$} & $\begin{array}{l}\text { Pearson } \\
\text { Correlation }\end{array}$ & -.303 & 1 & .075 & .206 & $486^{* *}$ & $339^{* *}$ \\
\hline & Sig. (2-tailed) & .104 & & .694 & .276 & .006 & .000 \\
\hline & $\mathrm{N}$ & 30 & 30 & 30 & 30 & 30 & 30 \\
\hline $\begin{array}{l}\text { Info and } \\
\text { Communications }\end{array}$ & $\begin{array}{l}\text { Pearson } \\
\text { Correlation }\end{array}$ & $.565^{* *}$ & .075 & 1 & $381^{* *}$ & $.523^{* *}$ & $-.051^{* *}$ \\
\hline \multirow[t]{2}{*}{ System } & Sig. (2-tailed) & .001 & .694 & & .000 & .000 & .000 \\
\hline & $\mathrm{N}$ & 30 & 30 & 30 & 30 & 30 & 30 \\
\hline \multirow[t]{3}{*}{$\begin{array}{l}\text { Control } \\
\text { Activities }\end{array}$} & $\begin{array}{l}\text { Pearson } \\
\text { Correlation }\end{array}$ & $625^{* *}$ & .206 & $.781^{* *}$ & 1 & $.880^{* *}$ & $.230^{* *}$ \\
\hline & Sig. (2-tailed) & .000 & .276 & .000 & & .000 & .000 \\
\hline & $\mathrm{N}$ & 30 & 30 & 30 & 30 & 30 & 30 \\
\hline \multirow[t]{3}{*}{ Monitoring } & $\begin{array}{l}\text { Pearson } \\
\text { Correlation }\end{array}$ & $499^{* *}$ & $.486^{* *}$ & $.323^{* *}$ & $480^{* *}$ & 1 & $-.323^{* *}$ \\
\hline & Sig. (2-tailed) & .005 & .006 & .000 & .000 & & .000 \\
\hline & $\mathrm{N}$ & 30 & 30 & 30 & 30 & 30 & 30 \\
\hline \multirow[t]{3}{*}{$\begin{array}{l}\text { Financial } \\
\text { Performance }\end{array}$} & $\begin{array}{l}\text { Pearson } \\
\text { Correlation }\end{array}$ & .287 & $.739^{* *}$ & $.651^{* *}$ & $.730^{* *}$ & $.923^{* *}$ & 1 \\
\hline & Sig. (2-tailed) & .124 & .000 & .000 & .000 & .000 & \\
\hline & $\mathrm{N}$ & 30 & 30 & 30 & 30 & 30 & 30 \\
\hline
\end{tabular}

**. Correlation is significant at the 0.01 level (2-tailed).

Source: Computed by the Author

The findings from table (1) demonstrated that, there is a positive relationship between the dependent variable "financial performance" and the independent variables "control environment, risk assessment and control activities" and a negative relationship between "financial performance" and the independent variables "information \& communication and monitoring". The Pearson's correlation coefficient between financial performance and control environment is 0.687 , this means that the two variables move in the same direction. This implies that an increase in control environment increases the financial performance of Telecommunication Company. Information \& communication and monitoring affect financial performance negatively with a Pearson's correlation coefficient of -0.051 and -0.323 respectively. This implies that an increase in information \& communication leads to a decrease in financial performance. The same applies to monitoring.

\section{Regression Analysis}

The examination was directed to build up the connection between internal control and financial performance of Asiacell as a telecommunication company in Kurdistan 
Region. The analysis applied the statistical package for social sciences (SPSS) to register the estimations of the multiple regressions for the study. Below are the findings;

\section{Model Summary:}

Below table shows the summary of the regression analysis.

\section{Table 2 Model summary}

\begin{tabular}{|c|c|c|c|}
\hline Model & $\mathrm{R}$ & R Square & Adjusted R Square Std. Error of the Estimate \\
\hline 1 & $.884^{\mathrm{a}}$ & .669 & .09543 \\
\hline
\end{tabular}

Source: Computed by the Author

In order to explain the percentage of variation in the dependent variable "financial performance" as explained by the independent variables, the researchers used the regression model for determination ( $R$ Square) that is obtained from the above. Based on the analysis, the findings show that the independent variables contributed to $66.9 \%$ of the variation in financial performance as explained by adjusted $\mathrm{R} 2$ of $0.660 \%$ while $33.1 \%$ is explained by other variables outside the model and the error term.

\section{Analysis of Variance}

The study conducted an Analysis of Variance, in order to test the impact of the relationship between internal controls and financial performance of telecommunication company in Kurdistan Region. The findings were as shown below:

\section{Table 3 Analysis of variance}

ANOVA $^{\mathbf{a}}$
\begin{tabular}{|ll|l|l|l|l|l|}
\hline Model & Sum of Squares & df & Mean Square & F & Sig. \\
\hline \multirow{3}{*}{1} & Regression & 980 & 5 & 0.197 & 10.398 & $.000^{\mathrm{b}}$ \\
& Residual & 440 & 24 & .018 & & \\
& Total & 1.420 & 29 & & & \\
\hline
\end{tabular}

a. Dependent Variable: Financial Performance

b. Predictors: (Constant), Monitoring, Risk Assessment, Control Environment, Info and Communications System, Control Activities

Source: Computed by the Author

From table (3), F value of 10.398 is significant at $95 \%$ confidence level. This is because the $\mathrm{P}$ value is greater than 0.05 . The result means that control environment, risk assessment, information \& communication, control activities and monitoring have effect on financial performance directly.

\section{Test for Coefficients:}

This table demonstrates the level of significance on the variables, it also provides the standardized and unstandardized coefficients:

Table 4 Test for coefficients

Coefficients $^{\mathrm{a}}$

\begin{tabular}{|l|l|l|l|l|l|}
\hline Model & \multicolumn{2}{|l|}{ Unstandardized Coefficients } & Standardized Coefficients & Sig. \\
\cline { 1 - 5 } & B & Std. Error & Beta & & \\
\hline
\end{tabular}




\begin{tabular}{l|l|l|l|l|l|}
\hline (Constant) & -2.375 & .675 & & -3.519 & .002 \\
Control Environment & .515 & 0.82 & 0.535 & 6.276 & .000 \\
Risk Assessment & .030 & .102 & .027 & .296 & .770 \\
Info and Communications System & .015 & .001 & .141 & 1.562 & .131 \\
Control Activities & .231 & .120 & .122 & 1.931 & .065 \\
Monitoring & -.149 & -.235 & -.062 & -1.356 & -.011 \\
\hline
\end{tabular}

From table (4), the researcher sought to establish the relationships between internal controls and the financial performance in telecommunication companies. The following regression equation was obtained:

$\mathrm{FP}=-2.375+0.515 \mathrm{X} 1+.030 \mathrm{X} 2+0.015 \mathrm{X} 3+0.231 \mathrm{X} 4$

From the above findings, holding the various components consistent, financial performance is measured by proficient and powerful usage of internal controls. The consequences of the various regression models show that there is a positive connection between internal control and financial performance. This implies that a single unit increases the results of independent variables (control environment, risk assessment, control activities, information \& communication) at $0.515,0.030,0.015$, and 0.231 respectively. Monitoring has a negative beta coefficient of -0.149 , which indicates that one unit increases in monitoring will cause to decrease financial performance by 0.149 and the other indicators remaining constant. The consequence of the examination demonstrates that control environment, risk assessment, control activities, information \& communication influence the financial performance positively, with control environment has a higher significant impact. The outcome also shows that monitoring has a negative effect on the financial performance.

\section{Summary and Interpretation of findings}

According to the respondents, it was revealed that the majority of the HR employees in Asiacell were degree holders. On whether the functionality of the internal controls of the organization affects the financial performance of telecommunication company in Kurdistan Region. The results revealed that most Asiacell as a telecommunication company had a control environment as one of the functionality of internal controls that greatly impact on the financial performance in the company.

It was also found that Asiacell monitored their activities as part of the functionality of internal control systems. However, some of the telecommunication companies failed to provide checks and evaluation of control activities on on-going basis. This showed that, even though monitoring was an important function of internal control in the telecommunication company, but not all telecommunication companies implemented this practice.

The statistical results from the regression analysis show that there is a positive relationship between internal control and financial performance of Asiacell. This is demonstrated by the level of significance, which attained by each of the independent variables. The result illustrates that control environment has $\mathrm{r}=0.887$ at $\mathrm{P}=0.000$. Monitoring on the other hand shows that $\mathrm{r}=-0.323$ at $\mathrm{P}=0.124$, this indicates that monitoring has a weak relationship with the financial performance. The relationship being negative indicates that monitoring and financial performance move in opposite direction.

Table (2) shows the coefficient of determination and provided that the independent variables contributed to $66.9 \%$ of the variation in financial performance as explained by adjusted R2 of $0.669 \%$. This shows that the model was a good predictor. Table (3) shows the analysis of variance. From this table, the sum of squares due to regression is 
(0.98) as explained by five variables is more than the sum of squares due to residuals (0.44). This implies that the relationship of the variables according to degree of freedom of the variables is accurate. The results in the table means that control environment, risk assessment, information and communication, control activities and monitoring reliably predict financial performance.

\section{Conclusion}

The main objective of the research was to determine the relationships between internal controls and the financial performance (return on asset) of Asiacell as a telecommunication company in Kurdistan Region. By fully investing in robust internal control systems, Asiacell was able to reduce fraud. According to the findings of this paper, the outcomes determined that some smaller-scale telecommunication companies were in want of evaluations of control activities and independent process checks on a continual basis. In addition to this, financial constraints had rendered periodic reviews of the system more challenging. The study found that a positive relationship had been established between financial performance with independent variables for instance "control environment, risk assessment and information communication technology". The research also concluded that by investing in robust internal control systems telecommunication companies had significantly enhanced financial performance in contrast to those telecommunication companies that had insignificant internal control system.

Telecommunication companies employees may not be involved in financial improprieties, they are more subject to accusations when adequate controls do not exist. Staff members, management, and other shareholders are actively engaged in assessing internal accounting mechanisms in telecommunication companies, which is an essential area of the firm. To realistically rely on systems of internal control, it must be designed, maintained, and frequently reassessed. Unsatisfactory internal controls can complicate the efficacy of the telecommunication companies, as well as situate employs in a position where they may be induced to engage in unethical activities or accounting practices. When adequate controls are lacking, telecommunication companies employees are more likely to be involved in financial improprieties.

\section{Recommendations}

Our study advises Asiacell and other telecommunication companies to provide feedback to all the shareholders with respect to the operation of the system, as well as to strongly encourage and incentivize ethical principles. It is essential that qualified and professional internal and external auditors should be employed in telecommunication companies. To ensure proper control over access to resources and records, management must be fully committed to the operation of the system. It is important to realize this commitment, management must also put in place policies, procedures, and mechanisms that ensure their directives are effectively carried out.

\section{References}

Aikins. (2011), An examination of government internal audits' role in improving financial performance, Public Finance and Management, 11(4), 306-337, available at https://ssrn.com/abstract=2689405. 
Al-Matari, E.M., Al-Swidi, A.K., Fadzil, F.H. (2014), The Effect of the Internal Audit and Firm Performance: A Proposed Research Framework, International Review of Management and Marketing, Vol. 4, No. 1, 34-41, available at http://www.econjournals.com/.

Ary, D., Jacobs, L.C., Sorensen, C. (2010), Introduction to Research in Education, 8th edition, Wadsworth, Cengage Learning.

Asiligwa, G.R. (2017), The Effect of Internal Controls on the Financial Performance of Commercial Banks in Kenya, Journal of Economics and Finance, Vol. 8, No. 3, 92-105, available at http://www.iosrjournals.org/.

Babbie, Earl R. (2002), The basics of social research, Belmont, CA: Wadsworth, Thomson Learning.

Bowrin. (2004), Internal control in Trinidad and Tobago religious organizations, Accounting, Auditing and Accountability Journal, 17(1), 121-152, available at https://doi.org/10.1108/09513570410525238.

Bett, J.C., Memba, F.S. (2017), Effects of Internal Control on the Financial Performance of Processing Firms in Kenya: A Case of Menengai Company, International Journal of Recent Research in Commerce Economics and Management, Vol. 4, No. 1, 105-115, available at www.paperpublications.org.

Cadeza, S., Guilding, C. (2008), An exploratory investigation of an integrated contingency model of strategic management accounting, Accounting, Organizations and Society, Vol. 33, No. 7-8, 836-863, available at https://doi.org/10.1016/j.aos.2008.01.003.

Cahill, E. (2006), Audit Committee and Internal Audit Effectiveness in a Multinational Bank: A case study, Journal of Banking Regulation, 7(1/2), 160 - 179. available at https://doi.org/10.1057/palgrave.jbr.2340011.

Channar, Z.A., Khan, M., Shakri, I.H. (2015), Internal Control Effectiveness \& its Relationship with Financial Performance, Journal of Business Studies, Vol. 11, No. 2, 92-107.

COSO (2011), Internal Control- Intergrated Framework, Committee of Sponsoring Orgarnisations of the Treadway Commission, New York: PWC, available at https://www.coso.org.

COSO (1985, 1992), Committee of Sponsoring Organizations of the Treadway Commission. Internal Control over External Financial Reporting: A Compendium of Approaches and Examples, available at https://www.coso.org.

Collins, O.O. (2014), Effect of internal control on financial performance of microfinance institutions in Kisumu central constituency, Kenya. Scholarly Journal of Scientific Research and Essay, Vol. 3, No. 10, 139-155, available at www.scholarly-journals.com/SJSRE.

Cunningham, L.A. (2004), The Appeal and Limits of Internal Controls to Fight Fraud, Terrorism, Other Ills, GW Law Faculty Publications \& Other Works, 29J, Corp.L.267, available at http://scholarship.law.gwu.edu/faculty_publications.

Dixon, J.R., Nanni, A.J., Vollmann, T.E. (1991), An instrument for investigating the match between manufacturing strategy and performance measures, (Unpublished Paper), Boston University.

Ejoh, N., Ejom, P. (2014), Impact of Internal Control Activities on Financial Performance of Tertiary Institutions in Nigeria, Journal of Economics and Sustainable Development, 5(16), 133-143, available at http://iiste.org/Journals/index.php/JEDS/article/view/15344/15561.

Eniola, O.J., Akinselure O.P. (2016), Effect of Internal Control on Financial Performance of Firms in Nigeria (A Study of Selected Manufacturing Firms), Journal of Business and Management, Vol. 18, No. 10, 80-85, available at http://www.iosrjournals.org/. 
Mafiana, A.Z. (2013), Examining the Relationships between Internal Control Effectiveness and Financial Performance in the Nigerian Banking Industry, Walden University, ProQuest Dissertations Publishing, 1-123, available at https://search.proquest.com.

Gamage, C.T., Lock, K.L., Fernando, A.A.J. (2012), A Proposed Research Framework: Effectiveness of Internal Control System in State Commercial Banks In Sri Lanka, International Journal of Scientific Research and Innovative Technology, $1(5), 25-44$.

Hamed, A. (2009), A clear Look at Internal Control: Theory and Concept. Unpublished MBA Research Paper, University of Nairobi.

Hayes, R., Dassen, R., Schilder, A., Wallage, P. (2005), Principles of Auditing, An Introduction of International Standards on Auditing, second edition. Pearson Education Limited. Harlow. England.

Inusah, A. M. \& Abdulai, S. (2015), Assessing Internal Financial Controls of the Lands Commission of Ghana, European Journal Of Business, Economics and Accountancy, 3(3), 51-65, available at http://www.idpublications.org/.

Jensen, M.C., Meckling, W.H. (1976), Theory of The Firm: Managerial Behavior, Agency Costs, and Ownership Structure, Journal of Financial Economics, 341356, available at https://doi.org/10.1016/0304-405X(76)90026-X.

Jussi, N., Petri, S. (2004), Does Agency Theory Provide a General Framework for Audit Pricing?, International Journal of Auditing, 8(2), 253-262. available at https://doi.org/10.1111/j.1099-1123.2004.00094.x.

Kaplan. (2008), ACCA Study Text - Audit and Assurance London: Ftc Kaplan ltd., available at http://kaplan-publishing.kaplan.co.uk/accabooks/f8/Pages/complete-text.aspx.

Kumar, R., Sharma, V. (2005), Auditing Principles and Practice, Prentice-Hall of India Private Limited.

Lannoye, M.A. (1999), Evaluation of internal Controls, available at http://www.michighan.gov/documents/gf_master1_26775_7.pdf.

Mawanda, S.P. (2008), Effects of internal control systems on financial performance in an institution of higher learning in Uganda: A case of Uganda Martyrs University, Unpublished thesis, Uganda Matyrs University.

Ngari, G.M. (2017), The effect of Internal Controls on Financial Performance of Microfinance Institutions in Kenya, International Academic Journal of Economics and Finance, Vol. 2, No. 3, 112-140, available at http://www.iajournals.org/articles/iajef_v2_i3_112_140.pdf.

Ngwenya. (2013), Application of Internal Controls in NGOs: Evidence from Zimbabwe, Journal of Finance and Accounting, 1, 39-47, DOI: 10.12691/jfa-12-1.

Nyakundi, D.O. (2014), Effect of internal control systems on financial performance of small and medium scale business enterprises in Kisumu City, International Journal of Social Sciences and Entrepreneurship, Vol. 4, No. 1, 719-734, available at https://www.ijsse.org.

Olumbe, C.O. (2012), The relationship between internal controls and corporate Governance in commercial banks in Kenya, Unpublished thesis, University of Nairobi.

Rahmany, Halime (2013), Evaluating and improving internal control in organizations, The Journal of Auditing, No. 64, 78-86, available at https://www.ifac.org/publications. 
Shokoohi, M, Saeidi, P., Malekmahmoudi, S. K. (2015), Investigating the Relation Between Internal Control System and Financial Performance of Telecommunication Company of Golestan Province, Multidisciplinary International Peer Reviewed Journal, Vol. 3(2), 206-211, available at http://saussurea.org/.

Simmons, M.R. (1995), The Framework for Internal Control: A Strategic Approach to Internal Audits, 12-22, available at http://www.facilitatedcotrols.com/internalaudit/cosobsic.htm.

Treba. L.M. (2003), Evaluating internal controls: control self-assessment in Government, Journal of Finance and Accounting, 4(3), 55-67, available at https://www.gfoa.org/sites/default/files/EICLGMG.pdf.

Tuan, N. (2015), A Theoretical Model Studying the Impact of Internal Control on Performance and Risks of Vietnam Commercial Banks, International Conference on Accounting, Danang, Vietnam, 22 May 2015, Yokohama National University.

Uket, Joseph. (2012), The Impact of Internal Control Design on Bank's ability to investigate Staff Fraud, and Lifestyle and Fraud Detection in Nigeria, International Journal of Research in Economics and Social Sciences, 2, 32-43.

Vadiei, M.H., Kuchaky, S.M. (2008), Evaluating effectiveness of internal control system from the perspective of independent auditors and its effect on auditing process, The Journal of Development and Investment, No.2, 127-148.

Wainaina, S.W. (2011), An Evaluation of the Internal Control Function: The Case of Kenya Polytechnic University College, Unpublished MBA Thesis, University of Nairobi. Kenya Wee.

Whittington, O.R., Pany, K. (2001), Principles of auditing and other assurance services, New-York, Irwin/McGraw-Hill.

Woods, M. (2009), A contingency theory perspective on the risk management control system within Birmingham City Council, Manage, Account. Res., 20(1), 69-81. 